\title{
Reported Energy and Cost Savings from the DOE ESPC Program: FY 2019
}

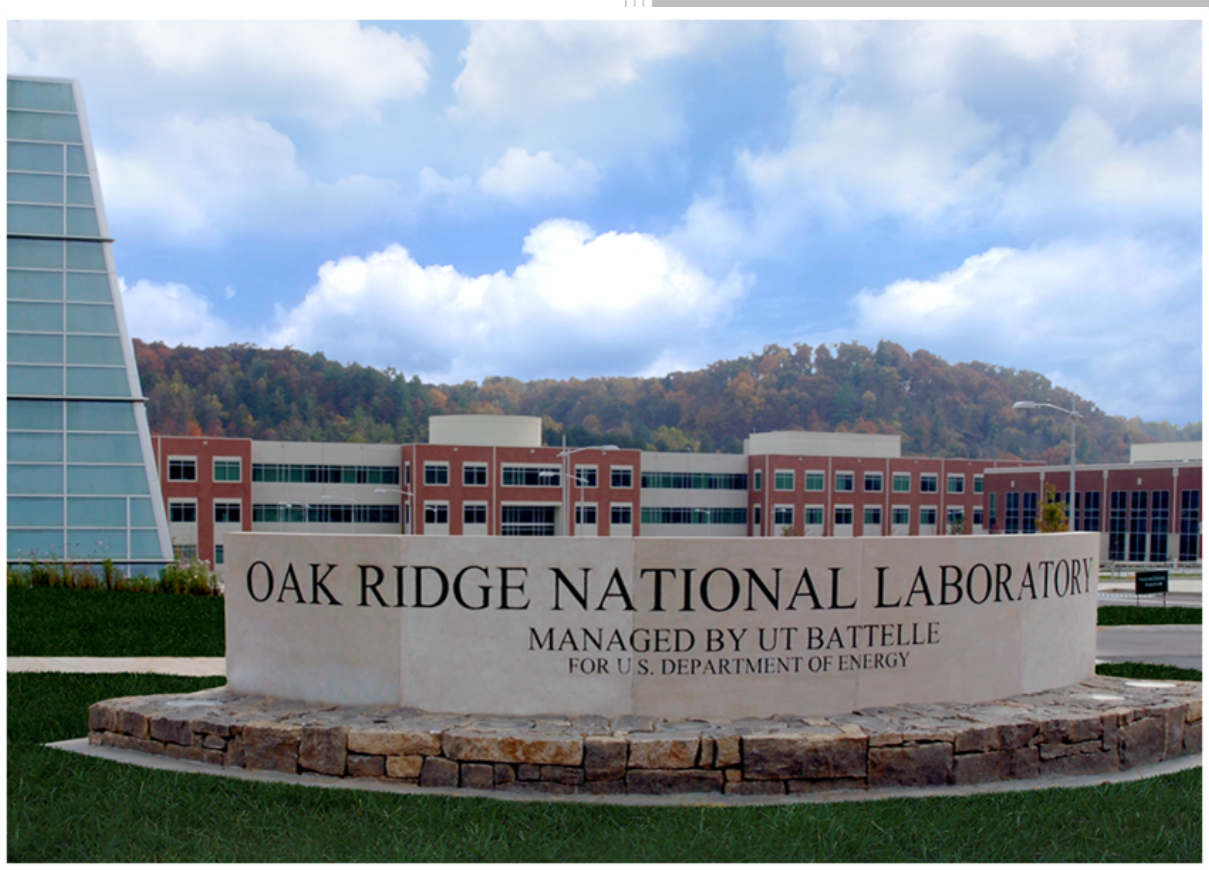

Christine E. Walker

Approved for public release. Distribution is unlimited. 


\title{
DOCUMENT AVAILABILITY
}

Reports produced after January 1, 1996, are generally available free via US Department of Energy (DOE) SciTech Connect.

Website www.osti.gov

Reports produced before January 1, 1996, may be purchased by members of the public from the following source:

\author{
National Technical Information Service \\ 5285 Port Royal Road \\ Springfield, VA 22161 \\ Telephone 703-605-6000 (1-800-553-6847) \\ TDD 703-487-4639 \\ Fax 703-605-6900 \\ E-mail info@ntis.gov \\ Website http://classic.ntis.gov/
}

Reports are available to DOE employees, DOE contractors, Energy Technology Data Exchange representatives, and International Nuclear Information System representatives from the following source:

Office of Scientific and Technical Information

PO Box 62

Oak Ridge, TN 37831

Telephone 865-576-8401

Fax 865-576-5728

E-mail reports@osti.gov

Website http://www.osti.gov/contact.html

This report was prepared as an account of work sponsored by an agency of the United States Government. Neither the United States Government nor any agency thereof, nor any of their employees, makes any warranty, express or implied, or assumes any legal liability or responsibility for the accuracy, completeness, or usefulness of any information, apparatus, product, or process disclosed, or represents that its use would not infringe privately owned rights. Reference herein to any specific commercial product, process, or service by trade name, trademark, manufacturer, or otherwise, does not necessarily constitute or imply its endorsement, recommendation, or favoring by the United States Government or any agency thereof. The views and opinions of authors expressed herein do not necessarily state or reflect those of the United States Government or any agency thereof. 
Buildings and Transportation Science Division

\section{REPORTED ENERGY AND COST SAVINGS FROM THE DOE ESPC PROGRAM: FY 2019}

Christine E. Walker, PhD, P.E.

Technical Project Staff Member

December 2020

Prepared by

OAK RIDGE NATIONAL LABORATORY

Oak Ridge, TN 37831-6283

managed by

UT-BATTELLE, LLC

for the

US DEPARTMENT OF ENERGY

under contract DE-AC05-00OR22725 



\section{CONTENTS}

ACRONYMS V

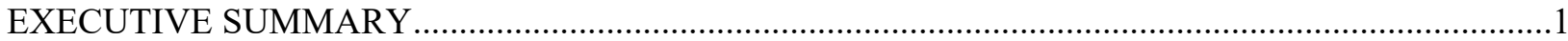

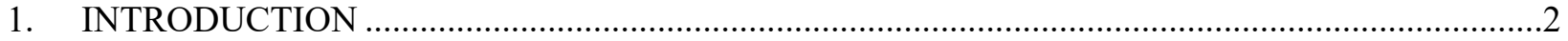

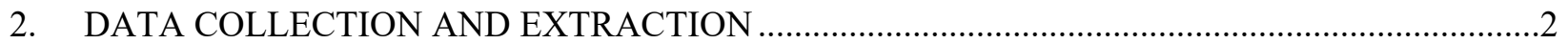

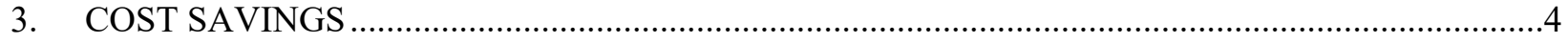

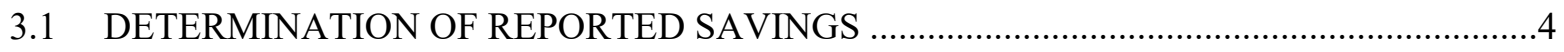

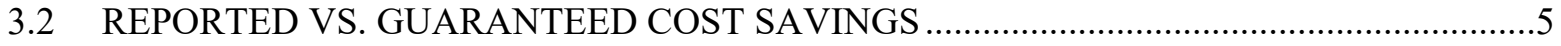

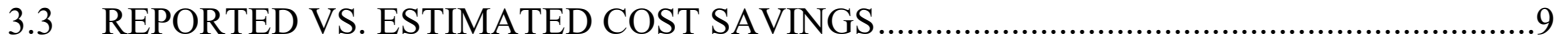

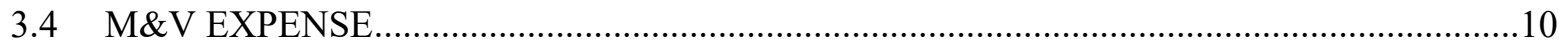

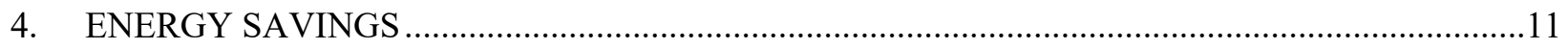

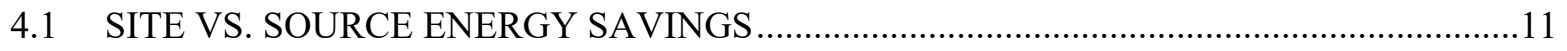

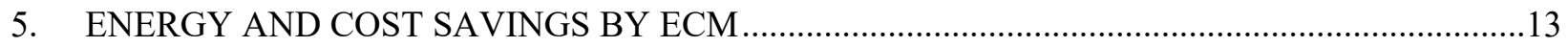

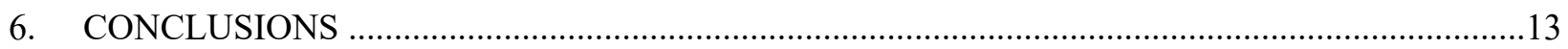

APPENDIX A. SECTION 502(E) GUIDANCE PROVIDING CREDIT TOWARD ENERGY EFFICIENCY GOALS FOR COST-EFFECTIVE PROJECTS WHERE SOURCE ENERGY USED DECLINES BUT SITE ENERGY USE INCREASES..... 


\section{ACRONYMS}

$\begin{array}{ll}\text { BTU } & \text { British thermal unit } \\ \text { DOE } & \text { Department of Energy } \\ \text { ECM } & \text { Energy Conservation Measure } \\ \text { ESCO } & \text { Energy Services Company } \\ \text { ESPC } & \text { Energy Savings Performance Contract } \\ \text { FEMP } & \text { Federal Energy Management Program } \\ \text { IDIQ } & \text { Indefinite-Delivery, Indefinite-Quantity } \\ \text { KWH } & \text { Kilowatt-Hour } \\ \text { LOC } & \text { Life of Contract } \\ \text { M\&V } & \text { Measurement and Verification } \\ \text { O\&M } & \text { Operations and Maintenance } \\ \text { ORNL } & \text { Oak Ridge National Laboratory } \\ \text { R\&R } & \text { Repair and Replacement } \\ \text { TO } & \text { Task Order }\end{array}$




\section{EXECUTIVE SUMMARY}

The objective of this work was to determine the realization rate of energy and cost savings from the U.S. Department of Energy's (DOE's) Energy Savings Performance Contract (ESPC) program based on information reported by the energy services companies (ESCOs) that are carrying out ESPC projects at federal sites. Information was extracted from 187 measurement and verification (M\&V) reports covering 183 projects to determine reported, estimated, and guaranteed cost savings and reported and estimated energy savings for the previous contract year. Additionally, the annual cost to perform M\&V was extracted from the individual project Task Order (TO) Schedules.

For all 187 reports, there was adequate information to compare project-level estimated, reported, and guaranteed cost savings. Reported cost savings accounted for both ESCO verified savings per the project's $M \& V$ plan and adjustments for government maintenance impacts to savings. For this group, the total reported cost savings for the reporting period addressed were $\$ 384.1$ million and total guaranteed cost savings were $\$ 350.9$ million. This means that, on average:

- ESPC contractors guaranteed $91.4 \%$ of the estimated cost savings

- projects reported achieving $100.1 \%$ of the estimated cost savings

- projects reported achieving $109.5 \%$ of the guaranteed cost savings

The M\&V performed for the period indicated that potential additional cost savings of $\$ 3.2$ million could be achieved through the restoration of equipment performance in accordance with the original operational parameters for impacted projects. Restoration of the $\$ 3.2$ million of identified potential cost savings would have resulted in achieved savings of $110.4 \%$ of the guaranteed savings.

For all 187 of the reports examined, there was enough information to compare estimated and reported energy savings. Based on site energy, estimated savings for those projects for the previous year totaled 14.110 million MMBtu, and reported savings were 14.155 million MMBtu, $100.3 \%$ of the estimated energy savings. For 187 of the reports examined there was adequate information to calculate source energy savings. Based on site-adjusted source energy, total estimated energy savings for the 187 reports were 16.171 million MMBtu, and reported savings were 16.426 million MMBtu, $101.6 \%$ of the estimated energy savings.

For all 183 of the projects examined, there was enough information to determine the cost to perform the annual $\mathrm{M} \& \mathrm{~V}$ audits. For this group the total annual expense for the ESCOs to perform annual M\&V audits and reporting was $\$ 7.78 \mathrm{M}$. This expenditure for annual $\mathrm{M} \& \mathrm{~V}$ services verified the occurrence of $\$ 384.1$ million in annual cost savings, which was $\$ 33.2$ million more than guaranteed and revealed opportunities to obtain an additional $\$ 3.2$ million in cost savings. 


\section{INTRODUCTION}

Among the most widely used vehicles for implementing energy savings performance contract (ESPC) projects in the federal government are the ESPCs administered by the U.S. Department of Energy's (DOE's) Federal Energy Management Program (FEMP). DOE ESPCs are indefinite-delivery, indefinitequantity (IDIQ) contracts designed to make ESPCs as practical and cost-effective a tool as possible for agencies to use. These "umbrella" contracts are competitively awarded to energy service companies (ESCOs) who have demonstrated their capabilities to provide energy projects to federal customers. The general terms and conditions are established in the IDIQ contracts, and agencies implement projects by awarding task orders to the DOE ESPC ESCOs. Using IDIQ contracts, agencies can implement ESPC projects in far less time than it takes to develop stand-alone ESPC projects. Since 1998, federal agencies have used DOE ESPCs to award task orders for 415 projects and install more than $\$ 6.6$ billion worth of energy improvements through the end of FY2019.

The objective of this report is to determine the realization rate of savings from the DOE ESPC program based on a review of the M\&V reports produced by all DOE FEMP ESPC projects that were in the performance period and had issued a report of September 30, 2019. Annual M\&V reports are required for projects awarded under the DOE IDIQ ESPC program that are in the performance period. Additional information on M\&V and FEMP guidance can be found on the FEMP website. ${ }^{1}$ Information was extracted from the provided reports to develop a database that includes estimated and reported energy savings by fuel type and estimated, reported, and guaranteed cost savings for each energy (and water) conservation measure (ECM) in each of the ongoing projects. The database was then used to determine fundamental information about the program, such as:

- the ratio of reported to guaranteed cost savings

- the ratio of reported to estimated cost savings

- the ratio of reported to estimated energy savings

\section{DATA COLLECTION AND EXTRACTION}

The first step in the data collection process was to determine exactly how many projects were in the performance period. As of September 30, 2019, DOE's list of awarded DOE ESPCs (maintained at http://energy.gov/eere/femp/downloads/doe-idiq-energy-savings-performance-contract-awarded-projects) contained 415 projects. The more recently awarded projects were either still in construction or still in the first year of the performance period, so that no $M \& V$ report had yet been produced. Some older projects had already completed the performance period or had been terminated for other reasons. We determined that there were 183 projects (producing 187 reports) that had produced at least one M\&V report during the 12-months preceding September 30, 2019. These 183 projects formed the study population, and their most recent $M \& V$ reports provided the data sources for this report.

The periods covered by the annual reports have various start dates depending on when the project's performance period began; however, the average start date is March 11, 2018, and the average end date is March 6, 2019. The contract performance year of the reports ranges from year 1 to year 19. In fiscal year 2019, 16 projects completed the first year of performance and generated an M\&V report. Table 1 presents the distribution of reporting years.

\footnotetext{
${ }^{1}$ https://www.energy.gov/eere/femp/measurement-and-verification-federal-energy-savings-performance-contracts
} 
Information was extracted from the collected $M \& V$ reports and used to populate a database that contains a separate record for each project, as well as the following information on each ECM for each project:

- Technology category of the ECM (these are specified in Attachment J-3 Energy Savings Performance Contract (ESPC) Technology Categories of the Attachments to the IDIQ Contract ${ }^{2}$

- $\quad \mathrm{M} \& \mathrm{~V}$ method used (FEMP Option A, B, C, or D)

- Estimated energy savings by fuel type (electricity, natural gas, oil, steam, etc.)

- Units of the estimated energy savings (kilowatt-hours [kWh], therms, MMBtu, etc.)

- Reported energy savings by fuel type

- Units of the reported energy savings

- Estimated cost savings from (1) reduced energy and utility bills and (2) reduced operations and maintenance $(\mathrm{O} \& M)$ and repair and replacement $(\mathrm{R} \& \mathrm{R})$ costs

- Reported cost savings from (1) energy savings and (2) O\&M and R\&R savings

Table 1. Number Of M\&V Reports By Contract Year of Performance

\begin{tabular}{cc}
\hline Contract Year & Number of Reports \\
\hline 1 & 16 \\
2 & 11 \\
3 & 15 \\
4 & 17 \\
5 & 10 \\
6 & 6 \\
7 & 22 \\
8 & 17 \\
9 & 16 \\
10 & 13 \\
11 & 10 \\
12 & 8 \\
13 & 3 \\
14 & 6 \\
15 & 5 \\
16 & 5 \\
17 & 4 \\
18 & 2 \\
19 & 1 \\
\hline
\end{tabular}

The database also includes the guaranteed cost savings for the reporting period. Typically, the guaranteed cost savings are not broken down by ECM; instead, the ESCO guarantees a dollar amount for the entire project for each contract year.

The quality of the $187 \mathrm{M} \& \mathrm{~V}$ reports examined varied widely, and many were lacking some of the information listed above. For example, some reports were missing the estimated cost savings. In these

${ }^{2}$ https://www.energy.gov/sites/prod/files/2019/05/f63/2017_generic_doe idiq_espc_contract.pdf 
cases, it was sometimes possible to obtain the missing information from the task order (TO) schedules for the project (also called $\mathrm{H}$ schedules or DO schedules in older projects). These schedules provide a concise listing of the important technical and financial aspects of the project. They are part of the final proposal and the TO award; DOE collects the TO schedules separately and maintains them in a central database.

For each project, Schedule TO-1 lists estimated and guaranteed cost savings by contract year. If there have been no modifications to the contract, the estimated and guaranteed cost savings listed in the M\&V report should correspond to the estimated and guaranteed cost savings listed in the TO schedules for that particular contract year. ${ }^{3}$ To fill in missing information, we assumed that if the guaranteed savings listed in the annual report matched the guaranteed savings listed in the schedule TO-1 for the corresponding contract year, then the estimated savings for the year were as listed in schedule TO-1. Likewise, for reports that did not list guaranteed savings, we assumed that if the estimated cost savings listed in the $\mathrm{M} \& \mathrm{~V}$ report matched the estimated cost savings listed in schedule TO-1 for the corresponding contract year, then the guaranteed cost savings for that year were the guaranteed cost savings listed in schedule TO-1.

Other reports were missing information on estimated energy savings. The estimated energy savings are a function of the ECMs installed and assumptions made about equipment efficiency, operating hours, weather, and other variables. The estimated energy unit savings are generally the same for each year of the contract. If no modifications are made to the contract, the estimated unit savings do not change. The estimated energy unit savings appear on schedule TO-4 for each ECM. They are used, along with the utility rates and escalation rates specified in the contract, to develop the estimated cost savings for each year of the contract that are listed in schedule TO-1. In the case of missing information on estimated energy savings, it was assumed that if the estimated cost savings listed in the M\&V report matched the estimated cost savings listed in schedule TO- 1 for the corresponding contract year, then the estimated energy savings were as listed in schedule TO-4.

\section{COST SAVINGS}

Although the primary objective of an ESPC project is to reduce energy use, the most important issue contractually is cost savings, which the ESCO guarantees on an annual basis. Energy use reductions are usually the largest source of the cost savings; however, savings may also result from reduced demand, improved power factor (which sometimes results in lower utility rates), and reduced water use. Reduced O\&M and R\&R costs are another major source of savings in ESPC projects.

\subsection{DETERMINATION OF REPORTED SAVINGS}

For purposes of this analysis, a project's reported savings was determined by adjusting the ESCO's verified savings (savings that was determined in accordance with the project's M\&V plan) by ESCO identified government impacts to savings (cost savings impacts due to government operation/maintenance of ESPC related equipment outside of the $M \& V$ plan parameters). Examples of government impacts to savings as noted in ESCO M\&V reports include changes to equipment operations or deferred equipment maintenance not related to mission-driven changes.

\footnotetext{
${ }^{3}$ Schedule TO- 1 lists costs and savings by contract year, and M\&V reports usually include the contract year in their title, for example, Fox Army Health Center: Year 6 Measurement and Verification Report, October 1, 2018September 30, 2019.
} 


\subsection{REPORTED VS. GUARANTEED COST SAVINGS}

Altogether, it was possible to determine reported and guaranteed cost savings for each of the 187 reports received. The total annual guaranteed cost savings for the 183 projects for the periods covered were $\$ 350,884,643$, and the total reported cost savings for the same period were $\$ 384,084,016$. In the aggregate, reported cost savings were $109.5 \%$ of the guaranteed cost savings.

In seven of the 187 reports, the reported annual cost savings were equal to the guaranteed cost savings. In five of these projects, M\&V Option A was used for all the savings. In the remaining 180 reports, the total reported cost savings were $110.6 \%$ of guaranteed cost savings, and 170 of these 180 projects reported cost savings exceeding the guaranteed cost savings by an average of $11.7 \%$.

Table 2 shows the percentage of reported cost savings across all projects in the data set subject to each $M \& V$ option.

Guaranteed cost savings shortfalls were reported in 10 of the 187 reports that did not appear to use Option A for all ECMs. The shortfalls range from less than $1 \%$ to $26 \%$ of the annual guaranteed savings, with a median value of $3.4 \%$ of the annual guaranteed cost savings and an average value of $6.2 \%$. In six of the ten cases, the shortfall was resolved through a reduced payment to the ESCO, and thus no longer have a shortfall. The M\&V reports identified three projects with shortfalls, plus one project with a de minimis, $0.4 \%$ shortfall. With these remaining four cases, the $\mathrm{M} \& \mathrm{~V}$ reports indicate that the shortfall was the agency's responsibility and/or was due to actions on the part of the agencies and was not the ESCO's responsibility. These four projects are in their first year of $\mathrm{M} \& \mathrm{~V}$ and under review to determine a resolution to compensate the government where appropriate and to correct the shortfall going forward. Agency sites experiencing shortfalls are contacted quarterly by Oak Ridge National Laboratory to review progress in resolution of outstanding project issues as part DOE FEMP's ongoing technical support services through the Life of Contract Services within the ESPC IDIQ program.

It is notable that for the group of 183 projects, $70.7 \%$ of the reported annual cost savings were due to reduced utility costs, and $29.2 \%$ were due to O\&M or energy-related cost savings.

Figures 1 and 2 illustrate the logic used for projects in Figures 3, 5, 6, and 7 to show estimated, guaranteed, and reported cost and energy savings, including savings shortfalls and savings exceeding the guarantee.

Figure 1 depicts a project with annual guaranteed cost savings of $\$ 50,000$, represented on the left side of the graphic. The right side of the graphic illustrates the results of the annual M\&V report, which showed savings of only $\$ 40,000$ and a savings shortfall of $\$ 10,000$. On the right side of Figure 1 , the bar is shifted downward so that a portion of it falls below the horizontal axis to represent the magnitude of the shortfall (in red). The bar remaining above the horizontal axis represents the reported savings, shown in yellow. The total height of the bar, red plus yellow, represents the guaranteed savings of $\$ 50,000$. 


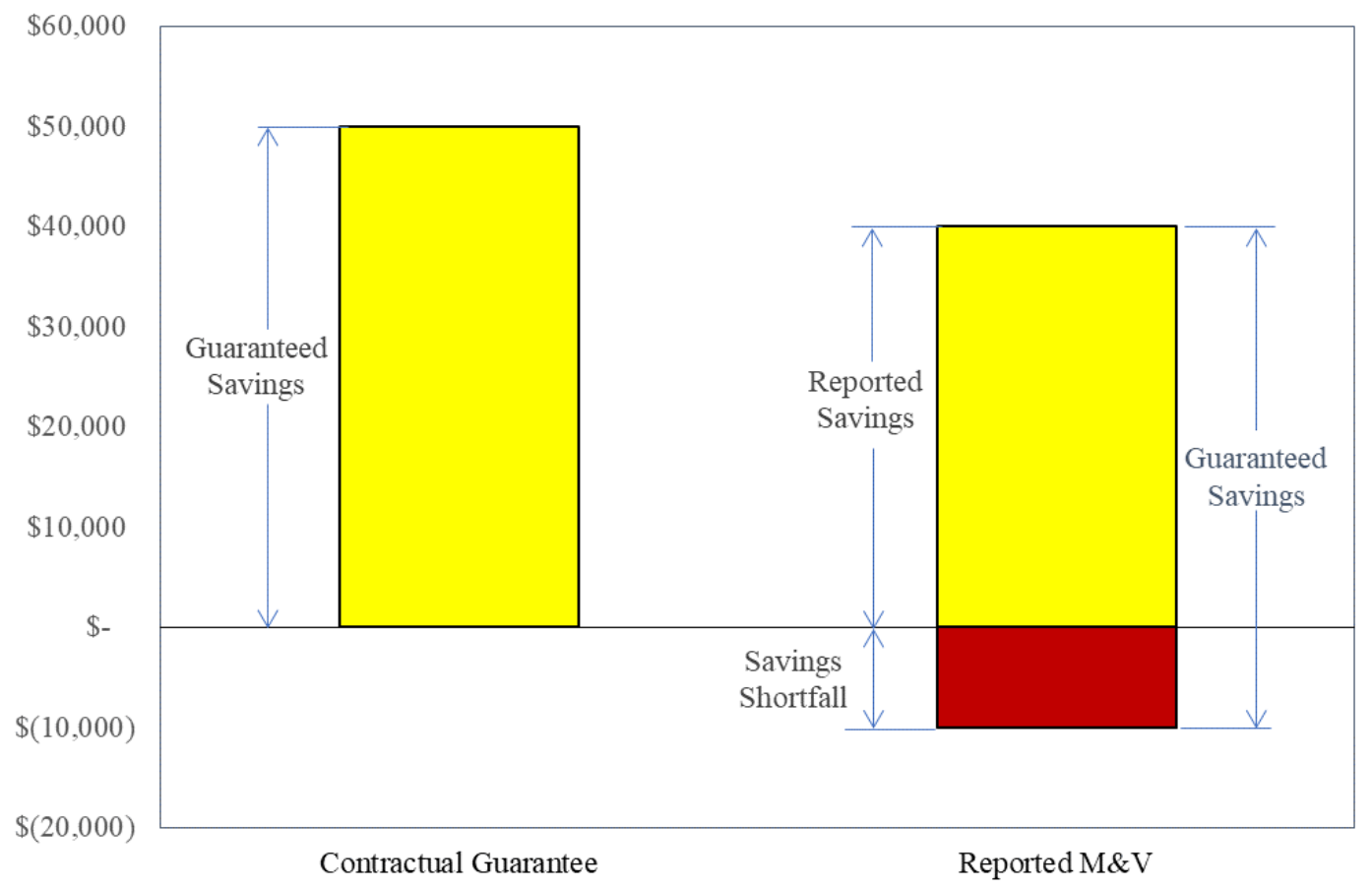

Figure 1. Guaranteed and reported savings for a project with a savings shortfall

Figure 2 illustrates how Figures 3, 5, 6, and 7 show reported savings exceeding guaranteed or estimated savings. Here, annual guaranteed savings are again $\$ 50,000$, but the $M \& V$ report shows a savings greater than $\$ 50,000$, and the bar from the left side of the figure moves upward on the right side by the amount of the surplus, which is shown in blue. The height of the yellow bar, which represents the guaranteed savings, does not change. The combined height of the yellow and blue bars represents the reported savings. 


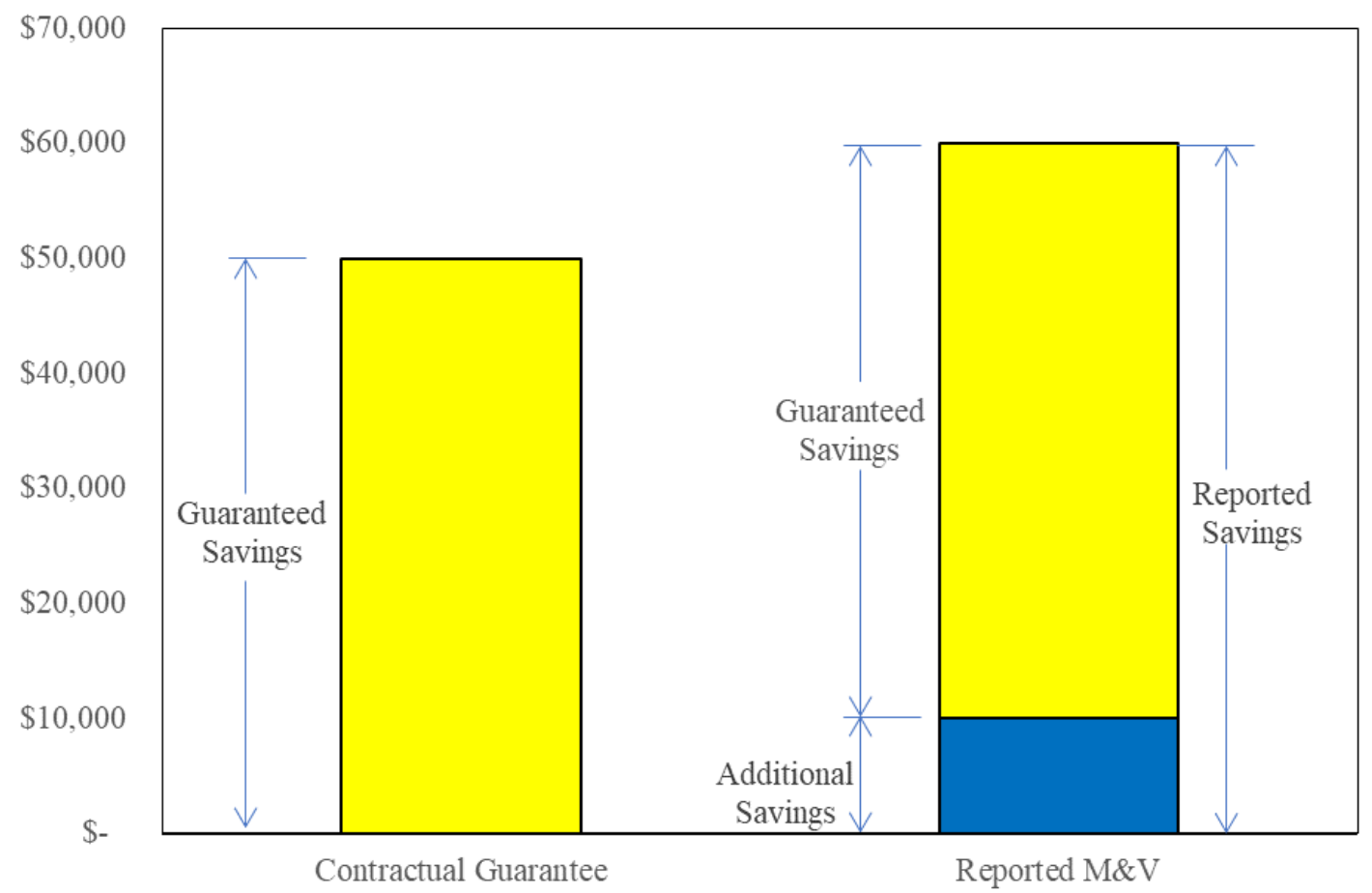

Figure 2. Guaranteed and reported savings for a project in which cost savings exceeds the guarantee

Using the scheme illustrated in Figures 1 and 2, Figure 3 presents the annual cost savings -along with shortfalls and reported savings exceeding the guarantee-as reported in the most recent $\mathrm{M} \& \mathrm{~V}$ reports for the 187 DOE ESPC M\&V reports analyzed. The project reports are arranged in descending order of reported annual cost savings.

One fact immediately evident from Figure 3 is the large range of cost savings delivered by the projects: the largest is reporting more than 1800 times the annual cost savings of the smallest. This means that program averages can be dominated by the performance of a small number of large projects, but it turns out not to be an overwhelming influence. When removing the 10 projects with the largest reported total cost savings from the data, the ratio of reported to guaranteed savings falls from $110.4 \%$ to $107.4 \%$. 


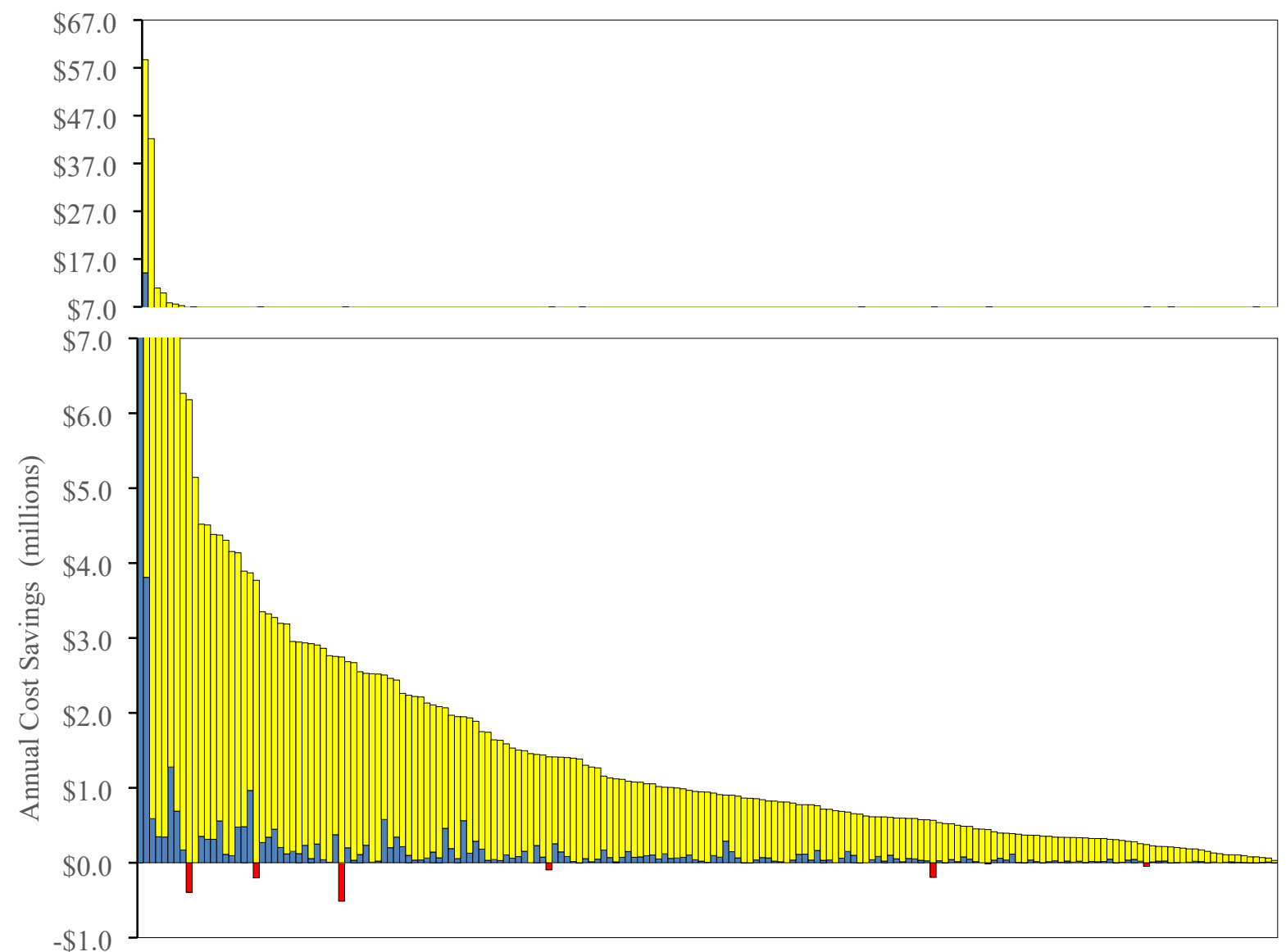

Figure 3. Annual cost savings from 183 ongoing DOE ESPC projects from 187 M\&V reports. Cost savings exceeding the guarantee are shown in blue; guaranteed cost savings shortfalls are shown in red. Where no shortfall occurs, the yellow bar is the amount of the guarantee. Where a shortfall occurs, the amount of the guarantee is the sum of the heights of the yellow and red bars.

Figure 4 presents the same information as Figure 3 but in a different way. In Figure 4, the bars represent the percentage of annual guaranteed cost savings reported in the annual M\&V reports. The bars are ordered from highest to lowest percentage of annual guaranteed cost savings. For projects with M\&Videntified shortfalls, Figure 4 illustrates where the payment to the ESCO was decremented and therefore no longer a shortfall; the remaining four projects where the $\mathrm{M} \& \mathrm{~V}$ report indicated a shortfall are under review to determine a resolution. The message is the same, however most projects report cost savings greater than the guaranteed savings, and only a few projects had cost savings shortfalls. 


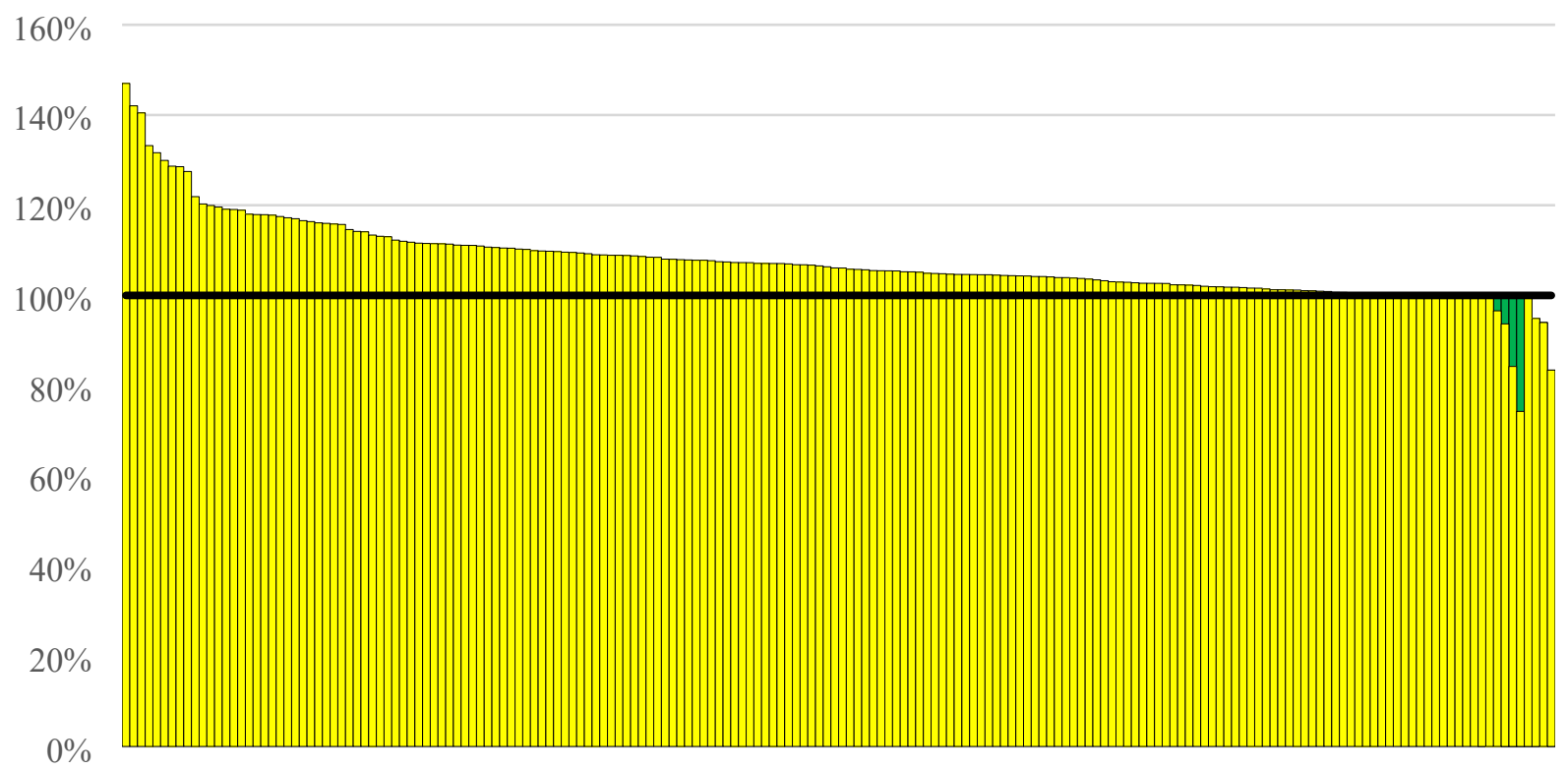

Figure 4. Percentage of guaranteed annual cost savings reported in 187 DOE ESPC IDIQ M\&V reports. Six projects with $\mathrm{M} \& \mathrm{~V}$-identified shortfalls were modified to lower contractor payments (indicated in green); the agency is not paying for savings not realized. The ESCOs are working with the agencies to correct the shortfall going forward. The remaining four projects are in their first year of performance and are under review to determine a resolution to compensate the government where appropriate and correct the shortfall going forward.

\subsection{REPORTED VS. ESTIMATED COST SAVINGS}

ESCOs use engineering models to estimate project energy savings, and then use contract utility rates and projected escalation rates to estimate cost savings for each year of the contract. The annual estimated (or "proposed") cost savings are included in each project task order on schedule TO-1 and should be included in the $M \& V$ reports. As noted earlier in Section 3, if estimated cost savings were not provided in the $\mathrm{M} \& \mathrm{~V}$ report, it was possible to extract the information from schedule TO-1. In all, we were able to determine estimated and reported cost savings for the same group of 183 projects identified previously.

For these 183 projects, the total estimated and reported cost savings for the reporting period were $\$ 383,759,770$ and $\$ 384,084,016$, respectively. Thus, in the aggregate, reported cost savings were $100.1 \%$ of the estimated cost savings. As stated previously, the total guaranteed cost savings for the 183 projects were $\$ 350,884,643$. Dividing the guaranteed savings by the estimated savings shows that ESCOs guaranteed an average of about $91.4 \%$ of the savings estimated for the reporting period.

Figure 5 shows the amount by which the reported cost savings exceeded or fell short of the estimated savings, in a manner analogous to Figure 3 . The projects are arranged in descending order of reported savings. 

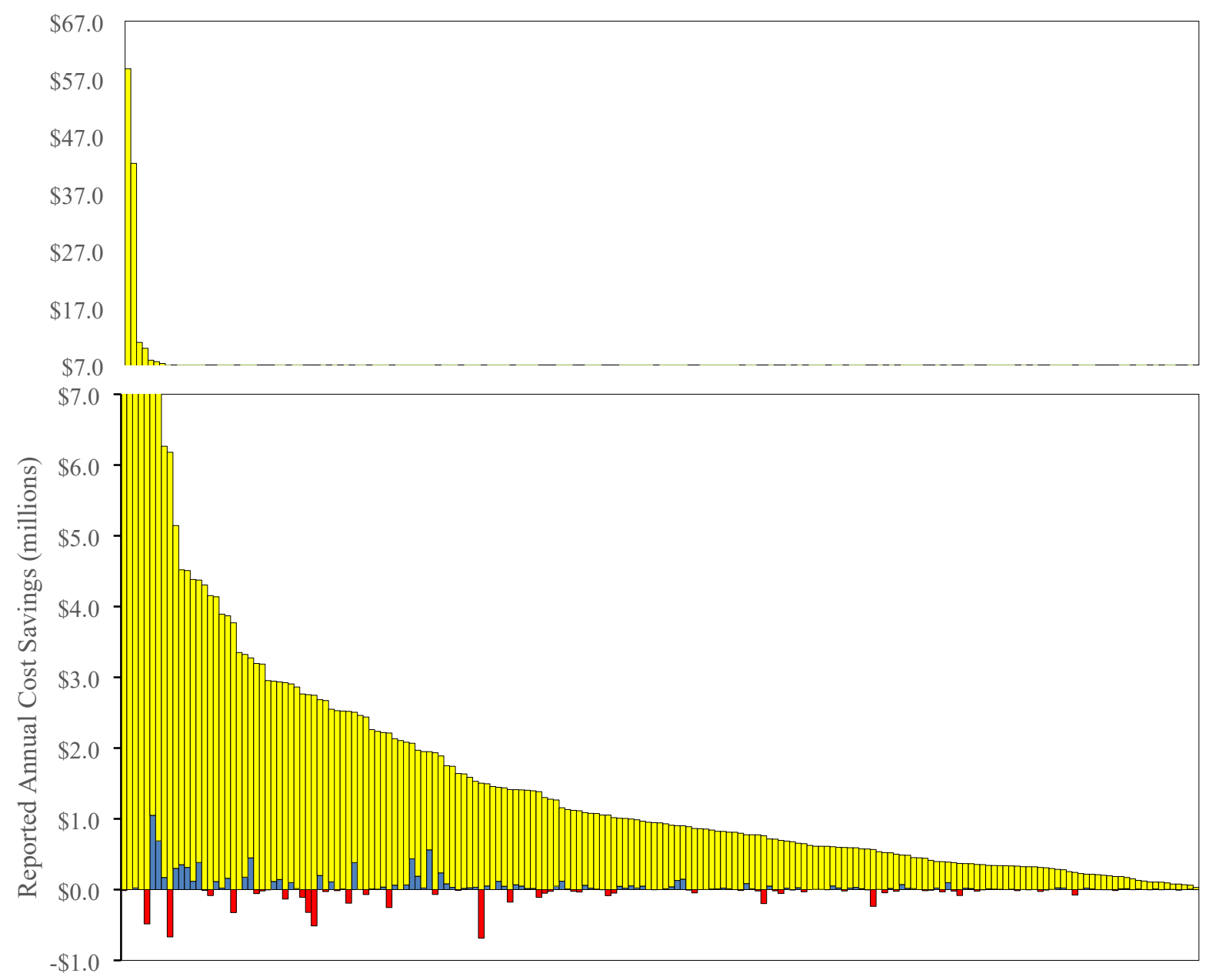

Figure 5. Reported and estimated annual cost savings from 187 DOE ESPC IDIQ M\&V reports. Reported cost savings above the estimated amount are shown in blue, and reported savings below the estimated amount are shown in red. Where reported cost savings equal or exceed the estimated savings, the height of the yellow bar is equal to the estimated savings. Where reported cost savings are less than the estimated amount, the estimated savings are equal to the height of the yellow and red bars combined.

\subsection{M\&V EXPENSE}

For all 183 of the projects examined, there was enough information to determine the cost for the ESCOs to perform the annual $\mathrm{M} \& \mathrm{~V}$ audits and reporting. This information was extracted from each project TO schedule as described in section 2. For this group the total annual expense for the ESCOs to perform annual $\mathrm{M} \& \mathrm{~V}$ audits and reporting was $\$ 7,780,801$. This expenditure for annual $\mathrm{M} \& \mathrm{~V}$ verified the occurrence of $\$ 384,084,016$ in cost savings which was $\$ 33,199,373$ more than guaranteed and revealed opportunities to obtain an additional \$3,177,544 in cost savings. By nature of the ESPC financial structure, annual $\mathrm{M} \& \mathrm{~V}$ expenses are paid for out of annual savings. The $\$ 7.78 \mathrm{M} \mathrm{M} \& \mathrm{~V}$ expenditure therefore represented about $2.0 \%$ of the total value of annual reported cost savings. 


\section{ENERGY SAVINGS}

Annual M\&V reports track energy savings as well as cost savings, since one of the primary motivations for implementing DOE ESPC projects is to meet energy use reduction goals. Energy unit savings are not guaranteed, but the ESCO estimates the energy savings that will occur in each reporting period, uses those savings to estimate cost savings, and guarantees some percentage of that amount. The annual M\&V report should present the energy savings realized during the period, as determined by the methods described in the M\&V plan.

Some of the $\mathrm{M} \& \mathrm{~V}$ reports examined were missing information on energy savings. As with cost savings, in some cases it was possible to determine the estimated energy savings from the TO schedules. Where the estimated energy savings were missing, if the guaranteed cost savings in the M\&V report was equal to the guaranteed savings listed on schedule TO-1 for the corresponding contract year, it was assumed that the estimated energy savings were as listed in schedule TO-4. Furthermore, it was sometimes possible to determine reported energy savings when this information was missing - if the reported cost savings were equal to the estimated cost savings listed in schedule TO-1, then it was assumed that the reported energy savings for the period were equal to the estimated cost savings listed in schedule TO-4.

\subsection{SITE VS. SOURCE ENERGY SAVINGS}

It is customary in the federal government to report energy savings on a site basis, counting electricity savings at 3,412 Btu/kWh and adding in other fuel savings in British thermal units (Btus). This is problematic for ECMs-such as combined heat and power plants-that offset the purchase of grid electricity through using fuel onsite (usually natural gas) because these plants typically increase site energy use, though they reduce overall energy use and cost. DOE's guidance on Section 502(e) of Executive Order 13123 was followed in these cases. The guidance allows a federal agency to adjust the verified site energy use by 8,438 Btu for each $\mathrm{kWh}$ of avoided electricity use to account for the reduction in source energy use.

We determined the reported and estimated energy savings for the reporting period for the 187 annual reports. On a site energy basis and adjusted per DOE guidance on Section 502(e) of Executive Order 13123, the estimated energy savings for the 183 projects were $15,619,792 \mathrm{MMBtu}$, and reported energy savings were $15,903,905 \mathrm{MMBtu}$, or $101.8 \%$ of the estimated savings. This is relatively close to the ratio of reported to estimated cost savings for these projects, which is $100.9 \%$.

The total project investment for the 183 projects for the reporting period was $\$ 2,843,631,150$, the reported savings represent 4,978 Btu/year for each dollar invested, site-adjusted to account for on-site generation.

Of the 187 reports, 75 reported annual energy savings less than the amount estimated for the period. For these projects, the reported energy savings average about $100.9 \%$ of the estimated energy savings.

Ninety five of the 187 annual reports described annual cost savings greater than the amount estimated for the period. On average, these projects reported $115.5 \%$ of the estimated energy savings.

Table 3 presents the net annual reported and estimated energy savings from the 183 projects by fuel type. "Net" savings means that no corrections were made for projects that increased site energy use while reducing source energy use. These numbers are of interest because they present the direct reductions in utility usage at the project sites. With the increase in installed distributed generation projects that typically consume natural gas to generate electricity, for the 183 projects natural gas usage across all installed ECMs and Technical Categories increased during this reporting period. Note that the ratio of reported to 
estimated savings varies by fuel type. In the aggregate, the projects report $107 \%$ of the estimated electricity savings, but $96 \%$ of the estimated natural gas savings for ECMs that are not within Technical Category 10 (Distributed Generation).

Table 3. Aggregate Net Annual Reported and Estimated Energy Savings by Fuel Type for 183 DOE ESPC Projects

\begin{tabular}{lrrrrr}
\hline & \multicolumn{2}{c}{ Reported } & \multicolumn{2}{c}{ Estimated } & \multicolumn{2}{c}{$\begin{array}{c}\text { Ratio of Reported } \\
\text { to Estimated }\end{array}$} \\
\cline { 2 - 5 } & $\begin{array}{c}\text { Savings } \\
\text { (MMBtu) }\end{array}$ & $\begin{array}{c}\text { Percentage } \\
\text { of total }\end{array}$ & $\begin{array}{c}\text { Savings } \\
\text { (MMBtu) }\end{array}$ & $\begin{array}{c}\text { Percentage of } \\
\text { total }\end{array}$ & \\
\hline Electricity & $4,843,750$ & $37.6 \%$ & $4,518,052$ & $35.6 \%$ & 1.07 \\
\hline Coal & $3,978,008$ & $30.9 \%$ & $3,978,008$ & $31.4 \%$ & 1.01 \\
\hline Steam & $2,921,537$ & $22.7 \%$ & $2,890,178$ & $22.8 \%$ & 1.01 \\
\hline Other & 999,339 & $7.8 \%$ & 993,017 & $7.8 \%$ & 1.00 \\
\hline Fuel Oil & 532,716 & $4.1 \%$ & 504,498 & $4.0 \%$ & 1.06 \\
\hline Chilled Water & 279,874 & $2.2 \%$ & 278,061 & $2.2 \%$ & 1.01 \\
\hline Natural Gas & $-681,782$ & $-5.3 \%$ & $-484,950$ & $-3.8 \%$ & 1.41 \\
\hline Total & $\mathbf{1 2 , 8 7 3 , 4 4 2}$ & & $\mathbf{1 2 , 6 7 6 , 8 6 3}$ & & $\mathbf{1 . 0 2}$
\end{tabular}

Energy use can also be reported based on source energy, which accounts for all the energy used at the power plant to produce the electricity delivered to the site. In general, source energy provides a better measure of the environmental impacts of energy efficiency and renewable energy measures than does site energy use. Given the data in Table 3 and an average 28.8\% electric conversion efficiency (as specified in DOE's guidance on Section 502(e) of Executive Order 13123), the estimated and reported source energy savings resulting from the 183 projects are 15,619,792 and 15,903,905 MMBtu, respectively. Thus, on a source energy basis, reported energy savings are higher than the estimated energy savings—at $101.8 \%$. 


\section{ENERGY AND COST SAVINGS BY ECM}

Table 4 presents information on the source of energy and cost savings by ECM technology category. The table shows, for example, that $35.5 \%$ of program-wide site energy savings and $36.7 \%$ of program-wide source energy savings are derived from ECMs involving distributed generation. These distributed generation ECMs are responsible for $15.9 \%$ of program-wide reported cost savings.

Table 4. Percent of Program-Wide Reported Site Energy Savings, Section 502(e) Reported Source Energy Savings, and Reported Cost Savings Delivered by Each Technology Category

\begin{tabular}{|c|c|c|c|}
\hline Technology Category & $\begin{array}{c}\text { Site } \\
\text { Energy } \\
\text { Savings }\end{array}$ & $\begin{array}{l}\text { Source } \\
\text { Energy } \\
\text { Savings } \\
\end{array}$ & $\begin{array}{l}\text { Reported } \\
\text { Cost } \\
\text { Savings }\end{array}$ \\
\hline Distributed Generation & $35.5 \%$ & $36.7 \%$ & $15.9 \%$ \\
\hline Building Automation/Controls & $13.7 \%$ & $13.3 \%$ & $12.8 \%$ \\
\hline Heating Ventilation and Air Conditioning & $12.7 \%$ & $12.0 \%$ & $13.9 \%$ \\
\hline $\begin{array}{l}\text { Chilled Water, Hot Water and Steam Distribution } \\
\text { Systems }\end{array}$ & $10.7 \%$ & $10.4 \%$ & $7.5 \%$ \\
\hline Boiler Plant Improvements & $7.7 \%$ & $7.9 \%$ & $18.4 \%$ \\
\hline Lighting & $7.7 \%$ & $7.4 \%$ & $12.8 \%$ \\
\hline Chiller Plant Improvements & $3.3 \%$ & $3.2 \%$ & $5.5 \%$ \\
\hline Water and Sewer Conservation Systems & $2.9 \%$ & $3.4 \%$ & $6.3 \%$ \\
\hline Renewable Energy Systems & $1.1 \%$ & $1.0 \%$ & $1.3 \%$ \\
\hline Ground Source Heat Pump & $1.0 \%$ & $1.0 \%$ & $1.2 \%$ \\
\hline Advanced Metering Systems & $0.9 \%$ & $0.9 \%$ & $1.1 \%$ \\
\hline Building Envelope Modifications & $0.8 \%$ & $0.8 \%$ & $1.0 \%$ \\
\hline Commissioning & $0.6 \%$ & $0.6 \%$ & $0.5 \%$ \\
\hline Motors and Drives & $0.6 \%$ & $0.5 \%$ & $0.4 \%$ \\
\hline Rate Adjustments & $0.3 \%$ & $0.3 \%$ & $0.4 \%$ \\
\hline Process Improvements & $0.2 \%$ & $0.2 \%$ & $0.6 \%$ \\
\hline Energy/Utility Distribution Systems & $0.2 \%$ & $0.2 \%$ & $0.2 \%$ \\
\hline Load Shifting & $0.1 \%$ & $0.1 \%$ & $0.1 \%$ \\
\hline Refrigeration & $0.0 \%$ & $0.0 \%$ & $0.1 \%$ \\
\hline Appliance/Plug-load Reductions & $0.0 \%$ & $0.0 \%$ & $0.0 \%$ \\
\hline
\end{tabular}

\section{CONCLUSIONS}

In federal ESPC projects, ESCOs use engineering formulas and other techniques to estimate the energy savings that will result from the conservation measures installed. Energy prices are then used to estimate the utility cost savings that will result from the estimated energy and water savings in each year of the contract. Other cost savings, including those that result from O\&M or R\&R savings, are added in to determine the total estimated annual cost savings. ESCOs then guarantee a percentage of the estimated cost savings. In the M\&V report, the ESCO reports both the energy savings and the cost savings that occurred during the reporting period. 
Based on an analysis of the most recent year's M\&V reports from all ongoing projects that have completed at least 1 year of performance, aggregate reported cost savings in the DOE ESPC IDIQ program are about $110 \%$ of aggregate guaranteed cost savings. Aggregate reported cost savings are approximately $100.1 \%$ of the estimated cost savings. This means that ESCOs are guaranteeing about $91.4 \%$ of the estimated annual cost savings. M\&V expense for the annual performance period examined, was found to be approximately $\$ 7.78 \mathrm{M}$ which funded the verification of $\$ 384.1 \mathrm{M}$ in cost savings and revealed opportunities to obtain an additional $\$ 3.2 \mathrm{M}$ in savings.

Energy savings can be calculated in terms of site energy use and source energy use. Based on site energy use, the projects analyzed reported $100.3 \%$ of estimated energy savings. Based on source energy use, the projects analyzed reported $101.8 \%$ of estimated energy savings.

Based on the information reported, the projects and program appear to be meeting their objectives in terms of realizing energy and cost savings. 
APPENDIX A. Section 502(e) Guidance Providing Credit Toward Energy Efficiency Goals for Cost-Effective Projects Where Source Energy Used Declines But Site Energy Use Increases 



\title{
APPENDIX A. SECTION 502(E) GUIDANCE PROVIDING CREDIT TOWARD ENERGY EFFICIENCY GOALS FOR COST-EFFECTIVE PROJECTS WHERE SOURCE ENERGY USED DECLINES BUT SITE ENERGY USE INCREASES
}

\author{
(Amended October 1, 2004)
}

\section{Background}

Section 502(e) of Executive Order 13123 requires the Secretary of Energy to "issue guidance for providing credit toward energy efficiency goals for cost-effective projects where source energy use declines but site energy use increases."

Section 206 of the Executive Order states:

Source Energy. The Federal Government shall strive to reduce total energy use and associated greenhouse gas and other air emissions, as measured at the source. To that end, agencies shall undertake life-cycle cost-effective projects in which source energy decreases, even if site energy use increases. In such cases, agencies will receive credit toward energy reduction goals through guidelines developed by DOE.

Energy measured at the point of use is termed "site energy." Energy measurement that accounts for the generation, transmission and distribution of the energy is called "source energy." Whichever way consumption is measured, cost-effectiveness remains the mandated criteria for assessing, selecting, and funding potential Federal energy efficiency projects. In June 1996, the Federal Interagency Energy Policy Committee (656 Committee) unanimously approved a policy statement that encourages cost-effective energy projects that result in reduced energy consumption regardless of whether that consumption is measured on a site basis or source basis.

The Department of Energy's Annual Report to Congress on Federal Government Energy Management will continue to report facility consumption both ways on an agency-wide basis and refers to sourcemeasured energy as primary consumption and site-measured energy as net consumption. When tracking performance toward the mandated reduction goals for buildings and facilities, Btu per gross square foot will be measured on a site basis, while source-measured consumption is also reported in accompanying tables.

Agencies should continue to report energy consumption as in the past, i.e., aggregated and submitted in the following units for each energy type.

$\begin{array}{ll}\begin{array}{l}\text { Energy Type } \\ \text { Electricity }\end{array} & \begin{array}{l}\text { Reporting Unit } \\ \text { (Megawatt Hours) }\end{array} \\ \text { Fuel Oil } & \text { (Thousands of Gallons) } \\ \text { Natural Gas } & \text { (Thousand Cubic Feet) } \\ \text { LPG/Propane } & \text { (Thousands of Gallons) } \\ \text { Coal } & \text { (Short Ton) } \\ \text { Purchased Steam } & \text { (Billion Btu) } \\ \text { Other } & \text { (Billion Btu) }\end{array}$

Site Conversion Factor

$3,412 \mathrm{Btu} /$ kilowatt hour

138,700 Btu/gallon

$1,031 \mathrm{Btu} / \mathrm{cubic}$ foot

95,500 Btu/gallon

$24,580,000 \mathrm{Btu} / \mathrm{short}$ ton

1,000 Btu/pound 
Based on these submissions DOE will calculate energy consumption in site-delivered Btu and Btu per gross square foot. DOE will also calculate Btu per gross square foot on a source basis.

Based on agency reporting for projects that reduce source energy use although site energy use increases, DOE will credit the source energy savings to the agency site energy use before the final calculation of goal performance in terms of site Btu per gross square foot.

Agencies may apply the credit themselves when reporting their performance to the Office of Management and Budget on their Agency Energy Scorecards.

\section{Calculating Project-Specific Source Energy Reductions}

Agencies can receive credit on their scorecard evaluations for life-cycle cost-effective projects where source energy declines and site energy increases. For each such completed project, agencies should calculate source energy savings for the reported fiscal year. Agencies may use the national average source conversion factors used by DOE or may choose factors for their state, utility, or steam provider. The national conversion factors used by DOE are:

\section{Electricity $\quad 11,850 \mathrm{Btu} /$ kilowatt hour \\ Purchased Steam 1,390 Btu/pound}

The electricity conversion factor includes energy lost in the generation process (66.5\%), electricity used in the utility plant (1.7\%), electricity lost in the transmission and distribution process $(3.0 \%)$, and electricity delivered to the customer's site $(28.8 \%)$. If a project uses a different factor, the source and each of these components should be documented along with the corresponding project worksheet. Agencies should use the following worksheet to document, for each applicable project, that source energy is reduced but site energy increases, and therefore the project qualifies for the Section 502(e) credit:

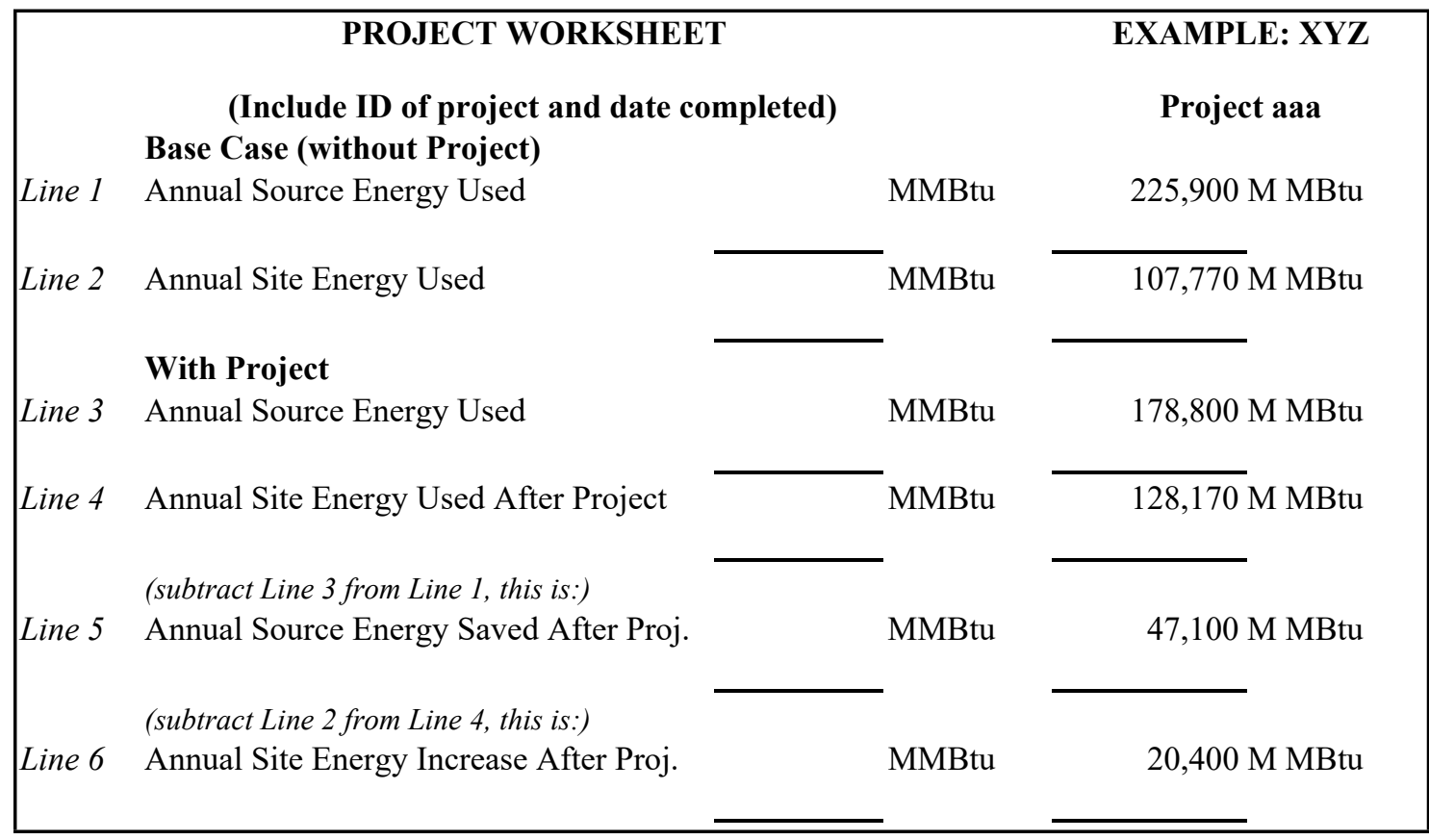


Qualifying projects receive a credit in the amount of the annual source energy savings (line 5 above), which is used to adjust downward the agency site energy use before the final calculation of goal performance in terms of site Btu per gross square foot. However, since qualifying projects have the characteristic that on-site utilization of energy forms other than electricity increase, while purchases of grid electricity are reduced; the agency's existing site energy use tracking system (e.g., the Defense Utility and Energy Reporting System for the Navy) will automatically recognize part of the credit. The purpose of the 502(e) adjustment is to account for the rest of the source energy savings credit.

For example, consider a large cogeneration (combined heat and power or CHP) project. Electricity is generated on-site with natural gas backed up with liquid fuel, and heat is recovered from the generation process and recycled to reduce purchases of boiler fuels, and/or to generate chilled water, further reducing grid electricity purchases. As a result of the project, fuel use for on-site power generation increases, fuel use for boilers decreases, and grid electricity purchases decrease. Site Btu and source Btu are substantially identical for all energy forms impacted by the project except for grid electricity, where $1 \mathrm{kWh}$ equals 11,850 source Btu (national average) but only 3,412 site Btu. With the exception of grid electricity, all forms of energy affected by the project have the same Btu value whether site or source. Therefore, backing out the grid electricity displaced by the project (self-generation, electric chiller load displaced by chilled water from recycled heat, etc.), on a source-Btu basis, is all that needs to be done. The agency's site energy tracking system will already have backed out displaced grid electricity because it no longer appears on the utility meter, but only at a rate of 3,412 Btu per $\mathrm{kWh}$. An adjustment is needed to account for the rest of the source energy savings, at a rate of 8,438 Btu per $\mathrm{kWh}(11,850$ minus 3,412). The 502(e) adjustment for the cogeneration project equals the displaced grid electricity in $\mathrm{kWh}$ per year multiplied by 8,438 Btu per kWh.

After calculating adjustments for each qualifying project, compile the data into the Compilation Worksheet format below:

\begin{tabular}{|l|l|c|l|c|}
\hline AGENCY COMPILATION WORKSHEET: (Agency Name) \\
\hline Name of Project & $\begin{array}{c}\text { Annual Site Energy } \\
\text { Increase with the } \\
\text { Project (Project } \\
\text { Worksheet Line 6) } \\
\text { MMBtu }\end{array}$ & $\begin{array}{c}\text { Annual Source } \\
\text { Energy Saved with } \\
\text { the Project (Project } \\
\text { Worksheet Line 5) } \\
\text { MMBtu }\end{array}$ & $\begin{array}{c}\text { 502(e) Adjustment to } \\
\text { Annual Site Energy } \\
\text { (Generally kWh of Grid } \\
\text { Electricity Displaced } \\
\text { Times 8,438Btu/kWh) } \\
\text { MMBtu }\end{array}$ \\
\hline 1$)$ & & & \\
\hline 2$)$ & Totals & & & \\
\hline 3$)$ & & & Section 203 (industrial/lab) \\
\hline \multicolumn{2}{|c|}{ Note: Credit is to be applied to } & Sec 202 (buildings) or & \\
\hline
\end{tabular}

In the table above, the right hand column total will be subtracted from the agency's total site energy use for buildings subject to the Section 202 goal, or from the agency's total site energy use for industrial/lab areas subject to the Section 203 goal, whichever the case may be, before calculating site Btu-per-grosssquare-foot. 


\section{Submission to DOE}

Agencies should submit their Compilation Worksheets to DOE to assure that the adjusted site energy is documented. Project data should be submitted for Section 202 and Section 203 on separate forms. Agencies need to submit their compilation sheet(s) for each year of their projects' lives so they can continue to get credit for all operating projects completed in previous years.

\section{Additional Benefits and Recognition of Projects that Reduce Source Energy}

(1) Impact on Greenhouse Gas Reduction Goal: Progress toward the new greenhouse gas reduction goal will be calculated based on source-measured energy. Therefore, projects that result in source energy reductions will directly contribute to an agency's performance toward the greenhouse gas reduction goal of Section 201 of the Order.

(2) Reductions in Source Energy per Gross Square Foot: Agency progress toward energy reduction goals will be tracked in the Annual Report to Congress on Federal Government Energy Management on a source-measured basis as well as on a site-measured basis. This will highlight agency achievements in source energy reductions as directed under Section 206 of the Order.

[Note: This guidance will be incorporated into the annual DOE Reporting Guidance for the Annual Report to Congress on Federal Government Energy Management.] 